\title{
The Contribution of Evaluation to Socialization and Externalization of Tacit Knowledge
}

\author{
The Case of the World Bank
}

\author{
MITA MARRA \\ Italian National Research Council, Italy
}

International organizations are increasingly focusing on organizational learning. The experience accumulated by development agencies throughout the world has become a source of organizational knowledge, which, according to Nonaka, is transferred through processes of socialization and externalization. Based upon three case studies and in-depth interviewing of World Bank managers and evaluators over two years, this article explores the contribution of evaluation to organizational learning. The study analyses the use patterns of evaluation as a source of knowledge within the World Bank. Findings show that participatory designs and processes favour socialization of tacit knowledge through interaction between organizational members. Theory-driven evaluations help externalize tacit into codified or explicit knowledge. Particular evaluation constructs - i.e. 'chilling effect' provide vocabulary that clarifies discussion and debate for strategic planning. Overall, managers value those evaluation properties associated with (a) first-hand data collection within country case studies, and (b) theory-driven analyses, externalizing tacit insights coming from the field.

KEYWORDS: development evaluation; externalization; organizational learning; participatory evaluation; socialization; tacit knowledge; World Bank

\section{Introduction}

What role does evaluation play as a source of knowledge within an organization? Conventional wisdom holds that evaluation contributes to organizational learning by examining the factors that affect change, such as leadership, incentives, human resources management, division of responsibilities, organizational structures and institutional competition (Argyris and Schön, 1978; Svensson, 1997). This claim may seem obvious and even mundane. What makes it an important and interesting assertion is that the interaction between evaluation use 


\section{Evaluation 10(3)}

and processes of organizational knowledge creation can be subtler than may be believed, and indeed, often counterintuitive.

This article aims to integrate the analysis of the use of evaluation within organizations with the notion of organizational knowledge. To date, empirical studies and theoretical discussions on evaluation utilization have classified different evaluation uses (e.g. instrumental, enlightenment, political), but have seldom incorporated organizational theory and research to explain their interaction within an organizational setting - though the instrumental and enlightenment uses are essentially organizational learning processes (Vedung, 1997; Rist, 1999). ${ }^{1}$ Also theories of organizational learning, such as the concept of 'doubleloop learning' (Argyris and Schön, 1978) have implicitly assumed a mechanistic view of the organization, whereby someone inside or outside an organization knows 'objectively' the right time and method for putting double-loop learning into practice (Nonaka, 1994). Evaluation has come to be uncritically seen as an intervention, such as an organizational development programme, to formulate collective lessons of experience and incorporate them into organizational theories of action (Argyris and Schön, 1978). But how and in what circumstances evaluation contributes to 'double-loop organizational learning' are yet no more than presumptions.

In line with Nonaka (1994), this article contends that organizations continuously create new knowledge by reconstructing existing perspectives, frameworks or premises on a day-to-day basis. 'In other words, double-loop learning ability is built into the knowledge-creating model, thereby circumventing the need to make unrealistic assumptions about the existence of a right answer' (Nonaka, 1994). Evaluation is then part of the organizational knowledge creation, not the only source of it. Programme designers and programme managers interact with a number of different actors: evaluators constitute one group and evaluation a set of knowledge to share among many others existing within the organization. The challenge is not only to detect what kind of evaluation use the organization endorses - whether for action, thinking or persuasion - but also and more importantly to explore how and to what extent evaluation reinforces organizational knowledge-creating processes over time (Goodman, 2000).

This article uncovers the relations between evaluation usage patterns and processes of knowledge creation by considering the specific instance of the World Bank, where managers attempt to realize development policy objectives. Though, as will become clear, core features of the World Bank evaluation studies are referred to - most notably, participatory, theory-driven, and ex post cost-benefit analyses - they are examined as embedded into patterns of organizational knowledge creation.

The aim is to go beyond the notion of organizational learning by identifying the contribution of evaluation to the socialization and externalization of organizational knowledge. Socialization enables an organization to convert tacit knowledge through interaction between individuals (Nonaka, 1994; Nonaka et al., 2000; Goodman, 2000). Policy designers are engaged in 'hobnob search processes' with a number of different actors where evaluators constitute one group only and their knowledge just one set among many; this is the interactive 
utilization of evaluation (Vedung, 1997). Externalization implies the conversion of tacit knowledge into explicit knowledge. The questioning and reconstruction of existing perspectives, interpretation frameworks, or decision premises lead to the creation of new knowledge (Nonaka, 1994).

Nonaka's constructs of socialization and externalization help, therefore, to qualify the processes through which managers and decision makers mobilize evaluative knowledge to change policies and practices. As knowledge emerges as an ever more important feature of competitive organizations, the major contribution of this article is the improved understanding of the role evaluation plays as tacit and explicit organizational knowledge in the design and implementation of development policies. In particular, the analysis highlights:

- the circumstances under which policy actors in the development community draw upon evaluation-based organizational knowledge in taking action;

- how this knowledge is used for thinking; and

- whether drawing upon evaluations 'improves' the quality of development decisions and policies.

This article is organized into the following sections:

- Methodology illustrates the methodology of the study, clarifying the rationale of the research design as well as the criteria for case-study selection and interviewees' sampling procedures.

- Participatory-evaluation Processes Help Share Tacit Knowledge analyses different participatory evaluation designs and processes and their contribution to the socialization of tacit knowledge.

- Organizational Constraints and Opportunities to Participatory Evaluations relates theory-driven evaluation approaches to knowledge externalization and concept creation through the playful and imaginative use of language.

- Theory-driven Evaluations Externalize Organizational Tacit Knowledge presents a number of examples of actual learning emerging from socialization and externalization of evaluative knowledge, demonstrating change in work practices and development policies.

- Implications for Management and Evaluation Practice draws a number of conclusions and implications on such issues as: (a) management styles and relations that may or may not favour evaluative-knowledge creation; (b) evaluation properties and components that may facilitate socialization and externalization; and (c) standards that managers apply to assess the value of evaluative knowledge.

\section{Methodology}

The case-study approach was appropriate to identify such evaluation properties and components as design, data collection and dissemination modalities that could favour evaluation usage through socialization and externalization processes of tacit knowledge within the specific context of the World Bank. Three evaluation studies were chosen to constitute the 'cases': 
- the Forestry Review of the 1991 World Bank Forestry Strategy;

- the Large Dam and Involuntary Resettlement Evaluation; and

- the Mid-term Evaluation on the World Bank Institute's Anticorruption Activities.

The cases concern evaluations of World Bank programmes in three major areas of development assistance: institutional strengthening, large infrastructure with social and economic implications, and environmental management and conservation. These three evaluations look at different aspects of development programmes: the forestry study focuses on the implementation of the World Bank 1991 Forestry Strategy; the large dams evaluation is an ex-post cost-benefit analysis; finally the mid-term evaluation on anticorruption is a theory-based study considering both implementation and outcomes of the first pilot anticorruption initiatives. The variation of cases was pursued to detect common patterns of usage and yield insights as to what kind of information policy makers perceived most/least useful (see Table 1). Between January 1999 and May 2001, research data was collected through: (i) semi-structured interviews of four different samples of informants within the World Bank; (ii) participant observation; and (iii) content analysis of official documents and evaluation reports.

Interview-data collection aimed to substantiate the interpretative categories of use for action, thinking and persuasion (as explained in Table 3 below) with four samples of informants in order to triangulate different perspectives, perceptions, opinions and descriptions (Stake, 1995). The samples of informants included: evaluators, high-level decision makers, country/programme managers, and experts. First, evaluators, including the authors of the selected evaluation studies, were interviewed to grasp the intended use of the evaluation studies they conducted and to reconstruct how evaluation studies were designed, implemented and disseminated within and outside the Bank. Second, decision makers were interviewed to gain insights on how they react to evaluation-based information, their pattern of evaluation use for policy making, and their attitudes toward evaluation. Third, programme managers were interviewed to understand which evaluation factors are associated with the willingness and experience to use evaluation for programme design and implementation. Finally, experts in the field of the selected evaluation studies (e.g. forestry, dam construction and anticorruption) were interviewed to gather their comments on the technical aspects of the studies. ${ }^{2}$ Table 2 specifies the composition of the four samples of informants and indicates the number of interviews conducted in each sample.

Undoubtedly, the specificity of the case studies as context- and topic-sensitive does not allow for sweeping generalizations. The World Bank is a unique institution and any analysis of its functioning is inherently related to its specific institutional and organizational arrangements, culture, practices, human resources, pattern of past performance and strategy for the future. Furthermore, the topics of the three studies are not neutral. The conclusions that are drawn - regarding the use of the forestry, dam building, and anticorruption studies, the changes that occurred, and the policy implications - relate only to these specific issues.

Also perceptions and opinions that were collected, though relevant, are 
Table 1. Key Features of Evaluation Studies Examined

\begin{tabular}{|c|c|c|c|}
\hline & Forestry Review & Large Dam Evaluation & Anticorruption Mid-term Evaluation \\
\hline $\begin{array}{l}\text { Policy/ } \\
\text { Programme } \\
\text { evaluated }\end{array}$ & $\begin{array}{l}\text { Implementation of the 1991 World Bank's } \\
\text { Forestry Strategy }\end{array}$ & $\begin{array}{l}\text { The evaluation concerned } 50 \text { Bank-financed } \\
\text { large dam constructions that were already } \\
\text { completed at the time of the evaluation. It } \\
\text { focused on economic, social and } \\
\text { environmental development vis-à-vis Bank } \\
\text { standards and safeguard policies }\end{array}$ & $\begin{array}{l}\text { The programme involved } \\
\text { investigative-journalism training }\end{array}$ \\
\hline $\begin{array}{l}\text { Policy/ } \\
\text { Programme's } \\
\text { outcomes of } \\
\text { interest }\end{array}$ & $\begin{array}{l}\text { The exploitation of forests through } \\
\text { logging and possible inconsistencies of } \\
\text { the Bank's role between forest } \\
\text { protection and poverty alleviation, } \\
\text { within developmental objectives, e.g. } \\
\text { where the Bank supports experiments } \\
\text { in logging. }\end{array}$ & $\begin{array}{l}\text { Improvement and expansion of power } \\
\text { generation, irrigation, domestic and industrial } \\
\text { water supplies }\end{array}$ & $\begin{array}{l}\text { Anticorruption outcomes and } \\
\text { institutional development }\end{array}$ \\
\hline $\begin{array}{l}\text { Date of final } \\
\text { report }\end{array}$ & 23/6/00: FY 2000 & I5/8/96: FY 1997 & FY 1998 \\
\hline $\begin{array}{l}\text { Location of the } \\
\text { evaluation sites }\end{array}$ & $\begin{array}{l}\text { World Bank Headquarters, and Brazil, } \\
\text { China, Cameroon, Costa Rica, India } \\
\text { and Indonesia }\end{array}$ & Desk review of 50 large dams & Tanzania, Uganda \\
\hline Methods & $\begin{array}{l}\text { I) Case study fieldwork; } \\
\text { 2) extensive consultation with } \\
\text { stakeholders; } \\
\text { 3) global policy review and six regional } \\
\text { portfolio reviews }\end{array}$ & $\begin{array}{l}\text { 1) Content analysis of documents on } \\
\text { large-dams projects financed by the Bank; } \\
\text { 2) survey questionnaire to implementing } \\
\text { agencies; } \\
\text { 3) informal interviews of operational staff. } \\
\text { This information was reviewed to identify } \\
\text { those projects that have been successful, }\end{array}$ & $\begin{array}{l}\text { I) Theory-driven approach; } \\
\text { 2) case study fieldwork; } \\
\text { 3) in-depth interviewing; } \\
\text { 4) content analysis of documents; } \\
\text { 5) social science empirical literature } \\
\text { review }\end{array}$ \\
\hline
\end{tabular}


Table 1. Continued

\begin{tabular}{|c|c|c|c|}
\hline & Forestry Review & Large Dam Evaluation & Anticorruption Mid-term Evaluation \\
\hline & & $\begin{array}{l}\text { overall, in supporting the objective of } \\
\text { sustainable development as well as those } \\
\text { instances where adverse impacts are } \\
\text { unacceptable. }\end{array}$ & \\
\hline Major findings & $\begin{array}{l}\text { The Bank has implemented the 199I } \\
\text { Forest Strategy only partially, and } \\
\text { through an increased number of } \\
\text { forest-related components in its } \\
\text { environmental lending. The effectiveness } \\
\text { of the strategy has been modest, as } \\
\text { well as the sustainability of its impact. }\end{array}$ & $\begin{array}{l}74 \% \text { of the } 50 \text { dams reviewed contributed to } \\
\text { energy production, flood control, water } \\
\text { supply for urban and industrial uses, and } \\
\text { irrigation. Resettlement was inadequately } \\
\text { managed in half the projects. } \\
\text { The } 50 \text { dams have a mixed record on the } \\
\text { management of environmental consequences. }\end{array}$ & $\begin{array}{l}\text { The awareness-raising approach to } \\
\text { change the cognition and mindset } \\
\text { of officials and journalists does } \\
\text { not guarantee empowerment at } \\
\text { the societal level. }\end{array}$ \\
\hline
\end{tabular}


Table 2. Interviewees' Profile

\begin{tabular}{lc}
\hline Interviewees' profile & No. of interviews \\
\hline Evaluators & 6 \\
Decision makers & 6 \\
Programme managers & 24 \\
Experts & 14 \\
Total & 50 \\
\hline
\end{tabular}

specific to interviewees' experience, understanding, beliefs, culture and context. Actually, the research itself with its emphasis on some specific evaluation information and findings might have induced respondents' perceptions regarding its impact on subsequent World Bank policies and programmes. It was necessary, therefore, to repeatedly probe interviewees' assertions through triangulation and document analysis. Last but not least, my internal position might have been the source of some limitations of the study. Being an 'insider' offered me, of course, a privileged position, access and understanding of the organizational culture, functioning and decision-making style. However, this status in turn reduced the 'objective' nature of the analysis. Despite these potential validity threats, the study offers cognitive insights on the relationships between evaluation use and organizational knowledge creation that can illuminate similar dynamics occurring within different organizational contexts.

\section{Participatory-evaluation Processes Help Share Tacit Knowledge}

According to Nonaka (1994; Nonaka et al., 2000), tacit knowledge is shared through the deep socialization of a project team, or what he calls a microcommunity of knowledge. Socialization means that members of the community not only come to understand each other's definition of shared situations but also agree on a common definition and 'justified true belief' about how to act in that situation. Knowledge then is created in the process of working together, benefiting largely from the mutual insight of organizational members to formulate an organizational advancement strategy (Nonaka, 1994; Nonaka et al., 2000).

In line with the bulk of evaluation literature (see Jackson, 1999; Biggs, 1998; Blackburn and Holland, 1997; Jacobs, 1996; Freedman, 1994; Barnsley and Ellis, 1992; Chambers, 1992; Cashman, 1991), case study findings suggest that participatory designs and interactive processes of data collection, analysis and dissemination are the most effective ways to socialize tacit knowledge within and outside an organization. For instance, in the case of the World Bank anticorruption evaluation, programme managers pointed out that collaborative interaction with the evaluation team helped clarify aspects of programme design and implementation. Although the evaluation study attempted to conceptualize and systematize all information acquired, programme managers reported that 


\section{Evaluation 10(3)}

informal, direct and systematic interaction with the evaluation team was the fastest and easiest way of learning the results while the study was ongoing (Marra, 2000). Programme managers got engaged in the evaluation process as joint players to uncover the premises of the programme logic to improve the design and performance of the anticorruption training offerings. ${ }^{3}$ Evaluators involved the programme managers not only as key institutional informants, but as members of the evaluation process to share beliefs about which actions work and which do not. This evaluative information is basically interactive and flows when the evaluation process is underway (Vedung, 1997; Kirkhart, 2000).

In the case of the large dam evaluation, programme managers and high-level decision makers both recognized that evaluators catalysed major international stakeholders' attention on the issues related to dam building, in an international event held in Gland in 1998, jointly organized with the IUCN (International Union for Conservation of Nature and Natural Resources) - the World Conservation Union. By socializing evaluative information on the social and environmental indirect costs associated with dam building, the Gland workshop provided a space for public debate and created the conditions for stakeholders from governments, non-governmental organizations (NGOs) and multilateral and bilateral agencies to begin an international dialogue. As one respondent noted:

It is useful to have an international public debate so as people from governments, and NGOs, and multilateral and bilateral agencies come together to discuss future policies.

The dam-evaluation team organized the Gland workshop not only to disseminate the study findings, but to provide an opportunity for addressing the fundamental questions regarding dams in an open space before 37 stakeholders, representing diverse interests from around the world (IUCN, 1997). The cost-benefit desk review of 50 Bank-financed large dams revealed the basic issues - resettlement and environmental damage - underlying the controversial aspects associated with dam projects. Initiated by evaluators, the Gland workshop became the place for decision makers to set new dam-safety priorities and begin to address resettlement problems. In this case, interaction between evaluators and decision makers occurred at the end of the evaluation process, when the study was completed and the report already issued. But, through interaction, evaluative knowledge became available to support discussion and future strategy, calling for a subsequent evaluation effort to address in greater depth the costs of resettlement and the development impact of dams. ${ }^{4}$

Also the evaluation of the Bank's 1991 forest protection strategy promoted a highly participatory process contributing to the broader forest policy review launched by the environmental department heads to change the Bank's global forestry policy. Different units and organizations across the Bank were involved in a comprehensive consultative effort to spur reflection around the core theme of sustainable forestry management. While evaluators looked back to evaluate the Bank's 1991 forest strategy, a Bank working group began to draw up a new strategy in mid-1998, mainly drawing on environmental reports and scholarly research. ${ }^{5}$ Later the working group formed a technical advisory 


\section{Marra: Contribution to Socialization and Externalization of Tacit Knowledge}

group of stakeholders at all levels to monitor the openness of the process and ensure that the voices of all relevant stakeholders were heard in regional, global and issues-based meetings.

Unlike the other two evaluation processes, the forestry evaluation team did not exclusively initiate the consultation and the analysis; nor was evaluation the only source of knowledge that was available or, most importantly, requested by managers. Nevertheless the evaluation process of data collection and analysis upgraded the debate not only within the Bank, but also among the major stakeholders in the development community and beyond - reaching as far as the Republic of China. ${ }^{6}$ All interviewees valued the independent analysis and research. ${ }^{7}$ The distinctive feature of the evaluation process was its participatory nature, able to triangulate different viewpoints to reach robust conclusions. Programme managers, as well as the decision makers and NGO members interviewed, acknowledged their own active participation in the study design phase, noting that they provided feedback on the findings while the study was underway, and reviewed the official final draft:

With the forestry study, the evaluation team has really made an effort to bring people around the table and talk this issue through ... not only Bank staff, but also NGOs, and the regions, and the borrowing countries.

Specifically, the forestry evaluation process involved people in government, development agencies, NGOs and the private sector. ${ }^{8}$ The evaluation design paper was translated into Balahasa, French, Mandarin, Portuguese and Spanish (languages spoken in five of the six case-study countries). From the outset, a fourmember advisory committee counselled the evaluation team on the design paper, the selection of country case studies, the preliminary findings, the consultation plan and the final report. Dissemination was also broadly widespread, beginning well before the report was officially issued and publicized outside the Bank. Besides discussing the preliminary report with Bank managers and shareholders in 1999 in Washington, DC, evaluators held multi-stakeholder country workshops in Brazil, China, India and Indonesia (between November 1999 and April 2000). ${ }^{9}$

The cases illustrated thus far show that managers value broad-based participatory studies, which, in turn, guarantee triangulation and more robust conclusions. Furthermore, interaction and participation may occur in different points in time, at the outset, during, or at the end of the study; yet, interactive processes enhance evaluative-knowledge creation and dissemination, detached from specific studies and reports. In fact, evaluative knowledge survives long beyond the life-shelf of formal reports, as shown by the dam-related evaluative debate (see Theory-driven Evaluations Externalize Organizational Tacit Knowledge below). In this specific case, the report was issued in 1997 while its own findings continued to feed the subsequent evaluation and research effort of the World Commission on Dams (WCD) and were still discussed at the Board of World Bank Executive Directors in 2001 vis-à-vis the changed international development conditions and priorities. ${ }^{10}$

Yet, the sharing of tacit evaluative knowledge required new organizational 


\section{Evaluation 10(3)}

arrangements, financial, human, and time resources, different kinds of evaluation project schedules, and new physical space to accommodate the work of microcommunities involved in evaluative-knowledge creation. Both the forestry and the anticorruption evaluations mobilized considerable financial resources to conduct the fieldwork, specific technical capacity and expertise to analyse the data, and time-consuming co-ordination among the different team members. Given the systematic time and budgetary constraints, the question is whether to employ human, organizational and financial resources to perform participatory evaluations of such scope. Another issue concerns the extent to which participatory strategies and modalities are compatible with organizational formal and informal rules, procedures, culture, as well as top-down and bottom-up communication channels. The next section seeks to address these issues.

\section{Organizational Constraints and Opportunities to Participatory Evaluations}

In line with Nonaka et al.'s conclusions (2000), case study findings suggest that the extent of interaction and participation within evaluation studies is a choice that has to be considered in an organization's advancement strategy - and is closely connected to establishing an overall enabling context. As emerged specifically from the forestry evaluation case study, when organizational information needs are explicitly related to the intention to reformulate the organizational strategy, there is a clear and articulated demand for evaluation to inform organizational actions and decisions.

The relevance of the forestry policy review called for a major knowledge-sharing effort to address the global problems related to forests. As the principal evaluator reported, from the very outset, the forestry evaluation was expected to inform not only Bank decision makers but also any parties interested in the issues the evaluation addressed. The intended audience included programme managers and members of civil society, who, as civic volunteers and opinion leaders in their communities, may have strategic interest in such issues as deforestation, sustainable management vs illegal logging, poverty reduction and preservation of the livelihood of local people. The evaluation effort involved not only human, and financial resources, but also a continuous process triggering dynamic co-operative relations among various functions and organizational departments as well as stakeholders outside the Bank. No one major department or group of experts had the exclusive responsibility for creating new knowledge, but evaluators facilitated the parallel knowledge-creation process, taking place simultaneously within top, middle and lower management as well as beyond the organizational boundaries. In this context, redundant information sped up concept creation around key evaluative issues leading to the reformulation of the World Bank forestry policy, as shown later on. By design the forestry study was instrumental to the broad-based review of the organizational strategy, as most respondents reported, as follows:

People writing the new forestry strategy have taken OED recommendations into account. 


\section{Marra: Contribution to Socialization and Externalization of Tacit Knowledge}

In the other two cases considered, there was no awareness of informational gaps to address existing organizational weaknesses. There was no intention to change the strategy for dam building or for anticorruption, nor was there any explicit demand for evaluation. Yet, evaluative-knowledge sharing was key to strategizing and reflecting upon organizational action, all the more when global issues were involved. Through socialization, unique knowledge became valuable to take action, to apply it to value-creating tasks and competence, and to capitalize such evaluative knowledge on existing corporate opportunities for strategic planning.

For instance, most interviewees agreed that the dams evaluation was the catalyst for the constitution of the WCD, which conducted the second phase of the review of the impact and performance of large dams throughout the world to set global standards for dam building and large infrastructure projects. ${ }^{11}$ Likewise, interviews suggested that the anticorruption evaluation paved the way for the complete restructuring of the anticorruption strategy with the introduction of new training courses addressing the weakness of the awareness-raising approach as the only mechanism to fight corruption. ${ }^{12}$

Of course, one might argue, following King and McGrath (2004), that knowledge-based aid contributed mainly to developing capacity within the Bank rather than addressing the expressed needs of Southern 'partners'. It is worth emphasizing, though, that in both the dams and anticorruption studies, the evaluation team took the initiative and bore the costs to open up the space for sharing evaluative information and debating its implications during the study process and at the end of the process with increasingly broader audiences within and outside the Bank. Even more, the forestry study sought participation from the outset, in the research-design phase and all along the implementation of the study until the report was issued, building upon the conscious overlapping of the organizational information, the different departments' activities, and the management responsibilities. Through a cross-fertilization process, the forestry study benefited from the policy review, where the evaluation, in turn, provided the opportunity to reflect on past experience, share lessons throughout the organization, and most importantly bring outside stakeholders' views and perceptions to bear on the policy-review process.

The analysis therefore suggests that across all three case studies presented thus far evaluators were left with the choice to create the conditions for processes of evaluative-knowledge generation and sharing across the organization. Yet, the forestry case study particularly highlights the implication for the organization to proactively mobilize financial, physical and technical resources for broad-based participatory-evaluation efforts to feed major organizational-advancement strategies. There is a need, though, to strike a balance between efficient organizational information processing and creative and redundant evaluative-knowledge generation, tapping into the existing pools of tacit knowledge, seeking effectiveness and competitiveness, and reinvigorating the quality of conversations taking place within and outside its organizational borders. Next, this article will analyse how tacit evaluative knowledge becomes explicit and codified to be used within and outside the organization. 


\section{Theory-driven Evaluations Externalize Organizational Tacit Knowledge}

The reconstruction of the logic underlying World Bank anticorruption initiatives and the 1991 forestry strategy was the major component of these two studies. Evaluators applied a theory-based approach, which systematically informed the process of data collection and analysis. By eliciting programme designers' own theories about how programmes were expected to work, evaluators 'disaggregated the assumptions into the mini-steps that are implied and confronted the leaps of faith and questionable reasoning that are (often) involved' (Weiss, 1980: 25). In this phase of knowledge creation, the micro-community of evaluators attempted to externalize the knowledge that managers possess in their day-today work, making explicit this tacit knowledge. This is obviously another crucial step, one that may ultimately result in the advancement of a programme or policy through a new product, process or service, such as the reformulated forestry policy, the revised dam safety standards, or the new anticorruption training courses.

To externalize knowledge means to express shared practices and judgments through language. A concept captures the blend of experience and imagination (Nonaka et al., 2000); it also comes about through assembling together ideas that already exist. Concepts like 'chilling effect' or 'awareness raising' embody the thinking of communities that have engaged in knowledge creation. With awareness raising, the anticorruption evaluation distinctively featured the Bank's first approach to fighting corruption through sensitizing journalists and other public officials. With 'chilling effect' the forestry study identified Bank staff's increasing disengagement in forest-related projects because of the high risk of being associated (in the minds of NGOs, environmental groups, and the general public) with environmental degradation and ecological disasters.

Figurative language, using metaphors in both the anticorruption and forestry studies, was of particular importance for concept creation. According to Nonaka et al. (2000: 234), 'members who can mentally visualize a concept may be able to catalyse and co-ordinate knowledge creation within an organization.' In this regard, programme managers reported that the metaphor of 'chilling effect' served to conceptualize their reluctance for forestry lending. The awareness raising was expediently used to shape thoughts and communication around the anticorruption initiatives. The evaluations helped organize and clarify discussion and debate (Vedung, 1997).

Through reporting, the theory-based approach of both studies allowed evaluators to externalize the logic underlying management actions and decisions. Uncovering the implicit theoretical premises embedded in anticorruption and forestry programmes favoured thinking and reflection upon programme design and implementation. This analytic decomposition of the Bank's programme logic helped programme managers clarify and systematize their implicit thinking. In fact, programme designers and decision makers operate on the basis of implicit and explicit assumptions, principles, and propositions that explain and guide their actions. ${ }^{13}$ Hence, reconstructing the programme theory - a specification of 


\section{Marra: Contribution to Socialization and Externalization of Tacit Knowledge}

what must be done to achieve the desired goals, what other important impacts may also be anticipated, and how these goals and impacts would be generated may facilitate understanding of programme outcomes for both formative and summative purposes; that is, aid the decision-making process and highlight the intended and unintended outcomes.

Drawing on Chen's (1993) notion of theory-based evaluation, case study findings indicate that both evaluations reconstructed the prescriptive and descriptive components of the Bank's intervention. Prescriptive theory (Chen, 1993) deals with what the structure of the programme should be in countries requesting World Bank assistance, and with ways to implement the programme. Evaluation of programmes based on prescriptive theory assesses whether and how the implementation of anticorruption initiatives or forestry loans differed from their original blueprints. Programme staff frequently experience problems in implementing programmes, since implementation is a very difficult and complicated process. The evaluation of the context and the overall strategy, therefore, helps programme designers and managers to understand whether failures resulted from programme design or from implementation. Descriptive theory (Chen, 1993), on the other hand, deals with the underlying causal mechanisms that link inputs, implementation processes, and outcomes. It specifies how the programme works by identifying the conditions under which certain processes arise and their likely consequences. It provides an understanding of the programme's potential by highlighting the intervening variables; diagnosing potential problems; and uncovering causal processes to understand why, for example, anticorruption activities did or did not work. For instance, in the anticorruption case, the prescriptive theory reassembled the various components of the Bank's strategy in dealing with the corruption problem by clarifying the goals and outcomes of the intervention (Marra, 2000). The descriptive theory looked into the assumptions about the causal relationships between the mechanism of raising awareness on corrupt practices among journalists and the desired outcome of corruption reduction (Marra, 2000, 2003).

In addition, special attention was paid to identifying elements of the programme's underlying logic with evidence from the social and economic sciences. As the principal evaluator pointed out, 'such an assessment is necessary, because no evidence exists that a policymaker's (or a practitioner, change agent, or Bank official's) assumptions are scientifically grounded. However, by the same token, no a priori assumption can be made to the contrary' (Leeuw et al., 1999: 30). According to the evaluation findings, the focus on awareness raising to change the cognition and mindset of officials and journalists was the weaker point in the programme logic, relying on the assumed 'automatic progression' from awareness of an unjust situation to intervening to bring it to an end (Marra, 2000, 2003). Furthermore, the empirical evidence did not justify the emphasis on empowerment as an effective mechanism to fight corruption. Even when individuals are empowered, the evaluation pointed out, it is not certain that empowerment at the social or organizational levels will follow (Marra, 2000, 2003).

In the forestry study, the evaluation team followed a similar approach, highlighting prescriptive and descriptive theoretical weaknesses in the design and in 


\section{Evaluation 10(3)}

the implementation process. The first design flaw was the Bank's assumption that developing countries would borrow Bank resources to conserve forests. Forests are global public goods that are likely to be under-produced, since forest conservation involves major positive externalities for forest-poor countries, while forest-rich developing countries bear its high costs. The 1991 policy assumed forest-rich countries would borrow from the Bank to finance the 'production' of such a global asset; yet, demand for forestry lending was low, particularly in Brazil. Drawing the implications for the Bank and developing countries, the evaluation made this logical inconsistency clear and explicit (OED, 2000). Another major flaw was found in the logging ban applied to all forests. The logging ban, in halting forestry production in any circumstances, underestimated the importance of forest products to the livelihood of indigenous people.

The study revealed the missing link between the Bank's 1991 forest strategy and the Bank's mission to reduce poverty, and questioned the unconditional logging ban enforced since 1991. The evaluation acknowledged the symbolic importance of the logging ban, which kept the Bank from being associated with deforestation and with commercial and illegal practices, but also pointed out the policy's unintended effect of indirectly contributing to deforestation (Marra, 2000, 2003). The logging ban was also at the origin of the 'chilling effect', that is, managers steering away from forestry lending (OED, 2000).

It is worth noting here that creating concepts and making them explicit contributes to strategic decisions, hence this process is itself a strategic concern. As shown in the two case studies, the externalization process led to reformulation of the premises underlying the original policy or programme in order to make it more effective. Next, a number of examples are presented of actual learning occurring through integrating evaluation-based information within broader organizational knowledge, linked both to specific work practices and strategic policies for international development.

\section{Examples of Change in Work Practices and Development Policies}

After searching for, socializing, documenting and externalizing evaluative information, organizational members are involved with a tangible form of knowledge, achieved by combining existing knowledge, products and procedures with the new evaluative concepts. Of course this is not a linear process whereby once a piece of evaluative information or a new evaluative concept are created, they come to be instrumentally incorporated into subsequent decisions or actions (Vedung, 1997; Weiss, 1980). The contribution of evaluation to organizational knowledge and thus to processes of change is not immediately apparent; it may remain 'dormant' or even unnoticed for a long time until a critical, related event brings the attention of organizational members back to the issue of the evaluation (Festinger, 1957; Kingdon, 1995; Henry, 2000).

As previously anticipated, in relation to the then-current debate on WCD, interviewees reported a renewed interest in the cost-benefit analysis of dam projects and also greater awareness of critical issues associated with dams addressed by the evaluation, such as resettlement plans, environmental assessments and safety 
issues. Especially in Europe and Central Asia, where most dam-safety projects are underway, interviewees expressed their concerns for minimizing the adverse technical and environmental effects produced by obsolescence, and degradation of the dam infrastructure. In the Africa and East Asian Pacific regions, an everincreasing demand for hydropower energy presented Bank staff with a daunting trade-off: whether to apply the costly Bank's safeguards or let the private sector take over. Those interviewed acknowledged that the Bank's involvement would help ensure better social, technical and environmental standards but Bank involvement might come at too high a price in terms of finance and damage to the Bank's reputation.

According to case-study findings, the contribution of evaluation to organizational learning may also occur incrementally, feeding directly work practices in the field. For example, regarding anticorruption activities, interviewees described efforts to re-engineer the first generation of media workshops. This included a series of electronic seminars for radio and TV journalists, allowing for better targeting both by geographical area and education level, decentralization in training delivery, and greater involvement of local organizations to produce more specific materials. At the same time, a whole new set of training and policy dialogues was launched to integrate the awareness-raising approach with a more broad-based participatory effort bringing public officials, politicians, and civil society to discuss corruption (Marra, 2000, 2003).

Regarding the forestry evaluation, the reformulated strategy:

- endorsed global and local partnerships; established concessional resources to supplement the regular Bank budget for study and analyses in this field;

- set up funding mechanisms to internalize global externalities;

- promoted sustainable forestry production, where appropriate, but ensured conservation in tropical moist forests; and

- strengthened the emphasis on poverty reduction and measures to improve the livelihood of indigenous people.

Such changes were in line with evaluative suggestions and recommendations.

As shown in Table 3, all three case studies presented thus far indicate that, both at the level of work practices and policy formulation, evaluative knowledge was incorporated into organizational action and strategic planning. Such findings suggest that evaluation use cannot be expected to be a linear process but rather it consists of a feedback loop, in which the knowledge created circles back to strategic efforts, continually altering or adapting the organizational advancement strategy as well as its vision, and action. This feedback loop may call for a new way of structuring the organization, point to new areas to exploit, identify new knowledge-creation projects, or suggest new barriers to dismantle in order to create future competitive advantages. Yet indifference and even preconceived judgments against evaluation may hamper the implementation of an advancement strategy. Next this article will highlight a number of implications for management styles and approaches, evaluation properties and underlying values that can enhance knowledge creation across the organization. 
Table 3. Relationship between Evaluation Usage Patterns and Processes of Organizational Knowledge Creation: Illustrations from the World Bank Evaluation Cases

\begin{tabular}{|c|c|c|c|}
\hline & Action & Thinking & Persuasion \\
\hline $\begin{array}{l}\text { Socialization } \\
\text { Implicit to Implicit }\end{array}$ & $\begin{array}{l}\text { Reduced lending for dam } \\
\text { building } \\
\text { Reduced lending for forestry } \\
\text { projects }\end{array}$ & $\begin{array}{l}\text { Appreciation of the participatory research technique adopted } \\
\text { for the forestry study } \\
\text { Appreciation of the country case study methodology adopted } \\
\text { by the Forestry Study } \\
\text { Discount of the credibility of the cost-benefit results on dams' } \\
\text { development effectiveness }\end{array}$ & $\begin{array}{l}\text { Concern for reputational } \\
\text { risks }\end{array}$ \\
\hline $\begin{array}{l}\text { Externalization } \\
\text { Implicit to Explicit }\end{array}$ & $\begin{array}{l}\text { Better quality of } \\
\text { compensation plans to } \\
\text { mitigate social damages } \\
\text { from large infrastructure } \\
\text { projects (use of } \\
\text { recommendations) }\end{array}$ & $\begin{array}{l}\text { Identification of the Forestry Strategy design flaws: a) public } \\
\text { good inefficiency; b) difficulty of enforcement of logging ban } \\
\text { (use of evaluation theory) } \\
\text { Identification of the Forestry Strategy implementation flaw: the } \\
\text { so-called chilling effect (use of evaluation findings and theory) } \\
\text { Raised awareness of the internal system of managerial } \\
\text { incentives: a) chilling effect; b) organization reputational risk } \\
\text { (use of evaluation findings) } \\
\text { Identification of the weak logical and empirical link between } \\
\text { raising awareness on corruption and fighting corruption (use } \\
\text { of evaluation theory and finding) } \\
\text { Identification of the logical and empirical link between Forest } \\
\text { Conservation and Poverty Reduction (use of evaluation } \\
\text { theory and findings) }\end{array}$ & $\begin{array}{l}\text { Justification for lending } \\
\text { for Sustainable } \\
\text { Forestry Projects } \\
\text { Gathering consensus for } \\
\text { changing the overall } \\
\text { approach to forest } \\
\text { conservation }\end{array}$ \\
\hline
\end{tabular}




\section{Implications for Management and Evaluation Practice}

As emerged from our findings, evaluation may contribute to change through providing empirically based information to support the design of new policies, programmes and implementation mechanisms; the framing of new problems and issues; or the justification of an intervention in the context of development assistance. The process of building evaluative knowledge takes place only when organizational members reflect on their actions, and the evaluation-based information is more than the specific information required immediately by each individual. The sharing of the extra information between individuals promotes the sharing of individual tacit knowledge and members share overlapping information, reducing the impact of managerial hierarchy and promoting mutual trust (Nonaka, 1994; Goodman, 2000).

Case-study findings suggest that the channels through which senior and lower managers hear about evaluation are basically informal, through socialization processes that go beyond the typical 'top-down' or 'bottom-up' management styles. Socialization of evaluation design, data collection, analysis and the reporting of findings democratizes the processes of knowledge creation. As shown above, the participatory evaluation approach of the forestry study made it possible to socialize specific information held exclusively by different departments at different management levels within and outside the Bank. The essence of a traditional bureaucratic machine is top-down information processing using division of labour and hierarchy (Goodman, 2000). Top managers create basic managerial concepts (the premises of decision making) and break them down hierarchically, in terms of objectives and means, so that subordinates can implement them (Nonaka, 1994; Goodman, 2000; Feldman and Khademian, 2002). Conversely, moving in the reverse direction, information is processed and transformed from the particular to the general. Frontline managers are immersed in the day-to-day details of particular technologies, products and markets. No one is more expert in the realities of an organization's business than they are. But, while these employees are deluged with highly specific information, they often find it extremely difficult to turn that information into useful knowledge (Nonaka, 1994; Goodman, 2000; Feldman and Khademian, 2002).

As interviews suggest, evaluation enters both management levels, making the process of knowledge creation participatory, and orienting chaotic information toward purposeful knowledge creation, through metaphors, symbols and concepts that catalyse the knowledge-creating activities around the organizational vision and strategy. The forestry study particularly promoted parallel evaluative-knowledge creation through extensive participation inside and outside the Bank at all levels, and meaningful concepts creation: i.e. the chilling effect, the logging ban with their country-specific variations.

But besides influencing management styles, evaluation promoted certain values (House and Howe, 1999) and preferences for some development actions over others. Indeed, the systematic focus of evaluations on countries' development needs, priorities, problems and gaps endorsed not only the perspective of the Bank - the corporate culture of the organization - but the genuine interest 


\section{Evaluation 10(3)}

of aid recipients, through independent analysis and research. The dams evaluation explicitly revealed the general relevance for development, highlighting the environmental and social implications of dams, and calling for stricter safety standards in Bank-funded operations to avoid social and environmental dumping. Also the forestry study highlighted the need to reconcile the illegal-logging ban with the need for sustainable forestry management services. Thus, I tend to accept only partially King and McGrath's argument whereby knowledge-based aid leads to greater agency certainty about what constitutes good development (King and McGrath, 2004).

As shown above, decision makers and managers accepted those properties and components of the evaluation reports associated with:

- first-hand data collection within country case studies; and

- theory-driven analyses, externalizing those tacit insights from the field.

Uncovering the tacit knowledge from the field and the day-to-day practice of development operations, the forestry and the anticorruption evaluations provided evidence of how well those policies and programmes 'worked' in different circumstances. Looking at the premises of programme design, the prescriptive aspects of strategies, and the causal mechanisms of programme activities both in Uganda and Tanzania, the anticorruption evaluation externalized the programme managers' implicit thinking and their leaps of faith. By identifying the direct and indirect costs and benefits associated with dams, programme managers and experts valued the way of thinking about large infrastructure projects with environmental and social externalities more than they valued a particular piece of information, finding or recommendation.

The externalization of this mostly tacit organizational knowledge helped organizational members to critically reflect upon their action and vision, while the mix between internal and external sources of evaluation-based information added to the methodological strengths and reliability of findings. The theories embedded implicitly and explicitly into programme designs, and the field research findings helped clarify the tacit premises of organizational action and validate them against empirical evidence. The evidence that those specific evaluations brought to the fore aimed to promote improvement through more effective policies and programmes.

These findings suggest that the knowledge-creation process builds on an organization's strategic ability to acquire, create, exploit and accumulate new knowledge continuously and repeatedly in a circular process, where individuals can link related concepts and areas of knowledge to allow problems to be viewed from many angles, and draw relationships between different sets of information. In line with Nonaka et al.'s (2000) conclusions, evaluation can align knowledge across different organizational layers, functions and roles. This process is in itself an endogenously produced knowledge system, whose specific components and properties (shown above) enable managers to create an organizational advancement strategy to exploit actual and future sources of competitive advantage. 


\section{Marra: Contribution to Socialization and Externalization of Tacit Knowledge}

\section{Notes}

1. For example, the large organizational literature on change and innovation is rarely cited and never discussed in any detail. Weiss's work, however, has incorporated some ideas from the organizational literature (Weiss, 1980). More recent research has begun to focus on organizational settings such as the US state legislators (Jonas, 1999; McIntire and Glaze, 1999), universities and schools (Preskill and Torres, 2000; Shulha, 2000; Rossman and Rallis, 1998), and non-profit organizations (Brett et al., 2000). By adopting a constructivist perspective, these latter studies conclude that evaluation leads to transformative learning and argue for a more complex understanding of use that positions the evaluator as a partner in the construction of knowledge within organizations (Rossman and Rallis, 1998).

2. The interviews were not taped for three reasons. First, based on prior experience, Bank staff are extremely cautious and reluctant to open up if their statements are recorded. Taping may have been perceived as not assuring confidentiality and hindered a trustful relationship between interviewer and interviewee. Second, Bank staff are typically very busy. A successful strategy to gain an interview was first to ask for a 20-30-minutes time slot as a conservative request and, once the interview was underway trying to stimulate the conversation and take additional time for probing. In such delicate circumstances, the tape could have diverted attention and undermined the quality of the conversation. Third, interviewing high-level managers and policy makers who are professional elites requires social psychology skills. Asymmetrical relations between the researcher and her 'objects' of study are not always clear-cut, as Pierce (1995) notes. My positioning within the organization needed to be considered in relation to race and gender concerns in the multicultural, multiethnic environment of the World Bank. In such circumstances, the tape could have added tensions and threats to both the interviewer and interviewee. All interview notes taken during the interview sessions were coded and analysed.

3. Based on semi-structured interviews.

4. Based on semi-structured interviews with programme managers.

5. Based on semi-structured interviews with programme managers.

6. The principal evaluator currently sits on the Chinese committee in charge of formulating a sustainable policy of forestry management in China (based on an interview with the principal evaluator).

7. Based on semi-structured interviews with programme managers.

8. Based on a semi-structured interview with the principal evaluator.

9. Based on a semi-structured interview with the principal evaluator.

10. Based on semi-structured interviews and the researcher's participant observation.

11. After a broad-based two-year investigation and analysis, in November 2000 the Commission released its report, entitled 'Dams and Development: A New Framework for Decision-making' (WCD, 2000).

12. The new so-called 'core courses' go beyond the awareness-raising approach for an integrated framework. This key component of the courses is to provide the participants with the necessary tool kit to enable them to design a coherent anticorruption strategy and discuss the challenges of integrating participatory and awareness-raising processes with concrete institutional reforms.

13. Based on semi-structured interviews with programme managers. 


\section{Evaluation 10(3)}

\section{References}

Argyris, C. and D. A. Schön (1978) Organizational Learning. Reading, MA: Addison Wesley.

Barnsley, J. and D. Ellis (1992) Research for Change: Participatory Action Research for Community Groups. Victoria, BC: Women's Research Centre.

Biggs, S. (1998) 'Beyond Methodologies - Coalition-building for Participatory Technology Development', World Development 26(3): 239-48.

Blackburn, J. and J. Holland (1997) Who Changes? Institutionalizing Participation in Development. London: Intermediate Technologies.

Brett, B., L. Hill-Mead and S. Wu (2000) 'Perspectives on Evaluation Use and Demand by Users: The Case of City Year', in V. Caracelli and H. Preskill (eds) The Expanding Scope of Evaluation Use, New Directions for Evaluation, 88. San Francisco, CA: JosseyBass.

Cashman, K. (1991) 'Systems of Knowledge as Systems of Domination: The Limitations of Established Meaning', Agriculture and Human Values 8(1/2): 49-58.

Chambers, R. (1992) Rural Appraisal: Rapid, Relaxed and Participatory. Brighton: IDS, University of Sussex.

Chen, H. T. (1993) Theory-driven Evaluation. London: Sage.

Feldman, M. and A. Khademian (2002) 'To Manage Is to Govern', Public Administration Review 62(5): 541-54.

Festinger, L. (1957) The Theory of Cognitive Dissonance. New York: Harper-Collins.

Freedman, J. (1994) Participatory Evaluations: Making Projects Work. Calgary: University of Calgary International Centre.

Goodman, P. S. (2000) Missing Organizational Linkages: Tools for Cross-Level Research. Thousand Oaks, CA: Sage.

Henry, G. (2000) 'Why Not Use?', in V. Caracelli and H. Preskill (eds) The Expanding Scope of Evaluation Use, New Directions for Evaluation, 88. San Francisco, CA: JosseyBass.

House, E. H. and K. R. Howe (1999) Values in Evaluation and Social Science Research. Thousand Oaks, CA: Sage.

IUCN - The World Conservation Union and the World Bank (1997) Learning from the Past, Looking at the Future. Workshop Proceedings, Gland, Switzerland, April 11-12, 1997. Washington, DC: World Bank. Available at: http://www.dams.org/docs/ largedams.pdf (site visited: 4 August 2004).

Jackson, E. (1999) Knowledge Shared: Participatory Evaluation in Development Cooperation. West Hartford, CT: Kumarian Press; Ottawa: IDRC.

Jacobs, S. (1996) Social Assessment and Participation: Methods and Tools. Washington, DC: World Bank.

Jonas, R. K. (1999) 'Against the Whim: State Legislatures' Use of Program Evaluation', in R. K. Jonas (ed.) Legislative Program Evaluation: Utilization-Driven Research for Decision Makers, New Directions for Evaluation, 81. San Francisco, CA: Jossey-Bass.

King, K. and S. McGrath (2004) Knowledge for Development? Comparing British, Japanese, Swedish, and World Bank Aid. London: ZED Books.

Kingdon, J. W. (1995) Agendas, Alternatives, and Public Policies, 2nd edn. Reading, MA: Addison-Wesley Educational.

Kirkhart, K. E. (2000) 'Reconceptualizing Evaluation Use: An Integrated Theory of Influence', in V. Caracelli and H. Preskill (eds) The Expanding Scope of Evaluation Use, New Directions for Evaluation, 88. San Francisco, CA: Jossey-Bass.

Leeuw, F., G. H. Van Gils and C. Kreft (1999) 'Evaluating Anti-Corruption Initiatives: 


\section{Marra: Contribution to Socialization and Externalization of Tacit Knowledge}

Underlying Logic and Mid-term Impact of a World Bank Program', Evaluation 5(2): 194-219.

McIntire, P. W. and A. Glaze (1999) 'The Use of System Modeling in Legislative Program Evaluation', in R. K. Jonas (ed.) Legislative Program Evaluation: Utilization-Driven Research for Decision Makers, New Directions for Evaluation, 81. San Francisco, CA: Jossey-Bass.

Marra, M. (2000) 'How Much Does Evaluation Matter? Some Examples of Utilization of the Evaluation of World Bank's Anticorruption Activities', Evaluation 6(1): 22-39.

Marra, M. (2003) 'Dynamics of Evaluation Use as Organizational Knowledge. The Case of the World Bank', PhD Dissertation. Washington, DC: The George Washington University.

Nonaka, I. (1994) ‘A Dynamic Theory of Organizational Knowledge Creation’, Organization Science 5(1): 14-37.

Nonaka, I., G. Von Krogh and I. Kazuo (2000) Enabling Knowledge Creation. How to Unlock the Mystery of Tacit Knowledge and Release the Power of Innovation. Oxford: Oxford University Press.

Operations Evaluation Department (2000) The World Bank Forestry Strategy - Striking the Right Balance. Washington, DC: World Bank.

Pierce, J. L. (1995) 'Reflections on Fieldwork in a Complex Organization', in R. Hertz and J. B. Imber (eds) Studying Elites Using Qualitative Methods. Thousand Oaks, CA: Sage.

Preskill, H. and T. R. Torres (2000) 'The Learning Dimension of Evaluation Use', in V. Caracelli and H. Preskill (eds) The Expanding Scope of Evaluation Use, New Directions for Evaluation, 88. San Francisco, CA: Jossey-Bass.

Rist, R. (1999) Program Evaluation and the Management of Government. New Brunswick, NJ: Transaction.

Rossman, G. B and S. F. Rallis (1998) Learning in the Field. London: Sage.

Shulha, L. M. (2000) 'Evaluative Inquiry in University-School Professional Learning Partnerships', in V. Caracelli and H. Preskill (eds) The Expanding Scope of Evaluation Use, New Directions for Evaluation, 88. San Francisco, CA: Jossey-Bass.

Stake, R. (1995) The Art of Case Study Research. Thousand Oaks, CA: Sage.

Svensson, K. (1997) 'The Analysis and Evaluation of Foreign Aid', in E. Chelimsky and W. Shadish (eds) Evaluation for the 21st Century. Thousand Oaks, CA: Sage.

Vedung, E. (1997) Public Policy and Program Evaluation. New Brunswick, NJ: Transaction Publishers.

Weiss, C. (1980) Social Science Research and Decision-Making. New York: Columbia University Press.

World Commission on Dams (2000) Dams and Development: A New Framework for Decision-making. London and Sterling, VA: EarthScan.

MITA MARRA is Research Fellow at the Italian National Research Council Institute for the Study of Mediterranean Societies. She has acted as consultant to the World Bank since 1998 on evaluation and public sector-reform projects.

Currently, she conducts research on public sector reform and local development policies. This article is based on a paper presented at the 5th Biennial Conference of the European Evaluation Society held in Seville, in October 2002. Usual disclaimers apply. Please address correspondence to: c/o Via P. Castellino, I I I-80 I3 I Naples, Italy. [email: mita.marra@issm.cnr.it] 